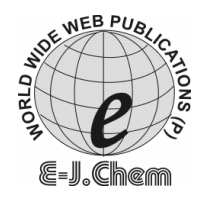

ISSN: 0973-4945; CODEN ECJHAO

E-Journal of Chemistry

http://www.e-journals.net

2009, 6(S1), S311-S323

\title{
Copper(II) Complexes of 4, 4- Diaminodiphenylsulphone: Synthesis, Characterization and Biological Studies
}

\author{
ADEDIBU C. TELLA* and JOSHUA A. OBALEYE \\ Department of Chemistry, University of Ilorin, Kwara state, Nigeria. \\ ac_tella@yahoo.co.uk
}

Received 3 March 2009; Accepted 5 May 2009

\begin{abstract}
Five complexes of copper(II) 4,4-diaminodiphenylsulphone have been synthesized. Copper salts of counter ion (sulphate, nitrate, chloride) and different reaction media (solvents) were used for the synthesis. The complexes varied in colour and composition. The compounds were characterized by conductivity, IR, UV, NMR and mass spectroscopies. The ligand coordinated to metal ion in a monodentate and bidentate manner. All the five complexes have tetrahedral configuration. The biological activities data showed that the complexes are more active against Esherichia coli, Klebbsiella pneumoniae and Staphylococcus aureus than the free ligand (4,4diaminodiphenyl sulphone). Antimalaria activities of the complexes and the ligand were investigated using mice infected with Plasmodium berghei. All the complexes exhibited lower activity than the ligand and chloroquine. The effect of administration of the complexes on alkaline phosphatase activities of kidney, liver and serum of Albino rats were investigated. The serum ALP activity showed no significant change $(\mathrm{P}>0.05)$, suggesting non-damaging effect on the plasma membrane of liver and kidney cells.
\end{abstract}

Keywords: 4,4-Diaminodiphenylsulphone, Alkaline phosphatase, Plasmodium berghei, ${ }^{1} \mathrm{H}$ NMR, Mass Spectroscopy.

\section{Introduction}

The sulfones are widely used as antileprosy drug and antimalarial drug as a combinational therapy. Combination of 4,4-diaminodiphenylsulphone with pyrimethamine has been effective in suppressing symptoms of malaria due to chloroquine resistant parasite Plasmodium falciparum $^{l}$. The efficacy of the therapeutic agent is known to be enhanced upon coordination to a metal ion ${ }^{2}$. The modification of existing antimalarial drugs by coordination to a metal centre has attracted considerable attention in recent years, especially to discover new drugs against chloroquine-resistant malaria parasite $e^{3,4}$. The ability of metal to combine with ligands and then release ligand in some process make them ideal for use in biological system. 
The most widely cation in the respect is $\mathrm{Cu}^{2+}$, since a host of low molecular weight copper complexes have been beneficial against several diseases such as tuberculosis, rheumatoid, gastric ulcer and cancer ${ }^{5}$. Garg and Sharma ${ }^{6}$ reported the synthesis of binuclear transition metal complexes. Biological activities of the complexes were not carried out. Our work on metal complexes of chloramphenicol and oxytetracycline showed that the complexes exhibited higher efficacy than the potent drugs ${ }^{7}$. In continuation of our studies on metal complexes of important biological ligands ${ }^{8,9}$. It was therefore, considered to synthesize and study the coordination pattern of 4,4-diaminodiphenylsulphone metal complexes with the hope that the resulting compounds might have biological potency and antimalarial activity higher than parent drugs. We decided to use copper salt as a source of metal ion because of the benefits of it over transition metal in that only very mild condition is necessary for binding reaction to occur and also has main advantage of forming an easy obtainable complex in the solid state ${ }^{10}$. It has been reported that presence of different copper ions such as chloride, bromide, nitrate and perchlorate affect the activity of complexes as the coordinating anions are varied. This paper reports our investigation on the effects of counter ions (sulphate, nitrate, chloride) and solvents (medium) on the physicochemical properties of 4,4-diaminodiphenylsulphone complexes of copper ion.

\section{Experimental}

4,4-Diaminodiphenylsulphone was purchased from Sigma chemical co (USA). All other solvents and reagents were of high purity (Aldrich and sigma) and were used without further purification. The metal salts used for complexation; Copper(II) sulphate pentahydrate, copper(II) nitrate trihydrate, copper(II) chloride hexahydrate were obtained from British Drug House Chemical Limited Company. Assay kit was obtained through Biochemistry Department, University of Ilorin, Nigeria, from Randox Laboratories Limited, Co. United Kingdom. Isolates Echerichia coli, Klebsiella pneumonia and Staphylococcus aureus were obtained University Teaching Hospital, Ilorin Nigeria. Albino rats (Rathus novergicuss) were obtained from the Department of Biochemistry University of Ilorin, Nigeria Plasmodium berghei and Mice were collected from IMRAT, University of Ibadan, Nigeria.

\section{Analyses and physical measurement}

Analytical measurements were carried out using Carbo-Erba Model 1106 Microanalyser. Infrared spectra in the range 4000-400 cm were obtained from samples in the form of $\mathrm{KBr}$ pellets using a Unicam FTIR spectrometer. The content of metal ions was determined by Atomic Absorption Spectroscopy with a Pelkin Elmer spectrometer model 3110. ${ }^{1}$ HNMR spectra were recorded with a Bruker AMX-200 Spectrometer in DMSO- $\mathrm{d}_{6}(\delta=2.60 \mathrm{ppm})$. Chemical shifts for proton resonances are reported in $\mathrm{ppm}(\delta)$ relative to tetramethylsilane. The electrospray mass spectra (Positive $\mathrm{Cl}$ - methane were recorded on a micro mass platform spectrometer and a Kratos concepts IS instrument using dimethylsulfoxide as solvents.

\section{Synthesis of the Complexes}

\section{Compound 1: [( $\left.\left.\mathrm{Cu}(\mathrm{DAP})_{2} \mathrm{Cl}_{2}\right)\right]\left(\mathrm{CH}_{3} \mathrm{OH}\right)_{2}$}

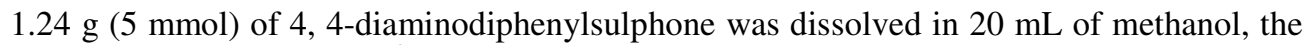
solution was heated at $60{ }^{\circ} \mathrm{C}$ for complete dissolution of the ligand. $0.85 \mathrm{~g},(5 \mathrm{mmol})$ of $\mathrm{CuCl}_{2} .2 \mathrm{H}_{2} \mathrm{O}$ in $10 \mathrm{~mL}$ of methanol was added to the above ligand solution. The greenish solution was refluxed for $2 \mathrm{~h}$ and cooled to room temperature. A green microcrystalline precipitate of complex was obtained after one week. The product was separated and dried at room temperature. Army green microcrystalline powder was obtained. 
The formation of the complex may be represented by the general equation below.

$$
\mathrm{MX}_{2} \cdot \mathrm{nH}_{2} \mathrm{O}+2 \mathrm{DAP} \underset{\text { Reflux }}{\stackrel{\text { Methanol }}{\longrightarrow}} \mathrm{M}(\mathrm{DAP})_{2} \mathrm{X}_{2}(\text { Solv })_{2} \cdot \mathrm{nH}_{2} \mathrm{O}
$$

Yield: $64 \%, \mathrm{M} . \mathrm{Wt}=694, \mathrm{~m} . \mathrm{p}>300{ }^{\circ} \mathrm{C}$, Anal.Calcd. for $\left.\left[\mathrm{Cu}(\mathrm{DAP})_{2}\left(\mathrm{CH}_{3} \mathrm{OH}\right)_{2} \mathrm{Cl}_{2}\right)\right], \mathrm{C} 44.95$; N 8.1; H 4.60; Cu 9.15, Found C, 44.88; N 8.0; H 4.4 Cu 9.12. IR (KBr, $\left.\mathrm{cm}^{-1}\right)$ 3600, 3443, 3360, 3231, 3141, 1623, 1594, 1493, 1433, 1340, 1284, 1145, 1109, 1077, 824, 648, 550. UVVis (Methanol) $\lambda_{\text {nm }} ; 278,335,753 .{ }^{1} \mathrm{H}$ NMR (DMSO-d $\left.{ }_{6}\right) \delta$ 7.25-7.45 $(4 \mathrm{H}, \mathrm{H}(26)), \mathrm{H}(6 \mathrm{~b}) / \mathrm{H}$ (2a) H (6a); 6.40-6.65dd (4H, H (3b)), H (5b)/ H (3b), H (5a).

\section{Compound 2: $\left[\mathrm{Cu}(\mathrm{DAP})\left(\mathrm{H}_{2} \mathrm{O}\right)_{2}\left(\mathrm{SO}_{4}\right)\right] \mathrm{H}_{2} \mathrm{O}$}

$1.24 \mathrm{~g}(5 \mathrm{mmol})$ of 4, 4-diaminodiphenylsulphone in methanol $(20 \mathrm{~mL})$ was added to $(5 \mathrm{mmol})$ $1.24 \mathrm{~g}$ of $\mathrm{CuSO}_{4} .5 \mathrm{H}_{2} \mathrm{O}$ in distilled water $(30 \mathrm{~mL})$, with continuous stirring for 2 hours. The greenish solid obtained was isolated by filtration, washed with mixture of methanol and water and dried at room temperature. A deep green solid powder was obtained.

Yield, 62\%, M.Wt, 443.5, m.p > $300{ }^{\circ} \mathrm{C}$. Anal. Calcd. for $\mathrm{C}_{12} \mathrm{H}_{16} \mathrm{~N}_{2} \mathrm{O}_{8} \mathrm{~S}_{2} \mathrm{Cu}$ : C 32.46; H 4.47; N 6.31; Cu 14.32. Found: C 32.39; H 4.50; N 6.36; Cu 14.24. IR $\left(\mathrm{KBr} \mathrm{cm}^{-1}\right) 3455,1628$, $1596,1279,1144,829,720,619.559 .{ }^{1} \mathrm{H}$ NMR (DMSO-d 6 ): $\delta 7.5$ (4H, H (26), 6.60-6.70 H (6b) / H (2a), H (6a); 6.01 (4H, H (3b)), H (5b), H (3a), H (5a) UV-Vis (DMSO) $\lambda$, nm; 278, 863.

Compound 3: $\left[\mathrm{Cu}(\mathrm{DAP})\left(\mathrm{NO}_{3}\right)\left(\mathrm{H}_{2} \mathrm{O}\right)\right] \mathrm{NO}_{3}$

4,4-Diaminodiphenylsulphone $(0.496 \mathrm{~g}, 2 \mathrm{mmol})$ was dissolved in $15 \mathrm{~mL}$ ethanol, the solution was heated for complete dissolution of the ligand and $\mathrm{Cu}\left(\mathrm{NO}_{3}\right)_{2} .3 \mathrm{H}_{2} \mathrm{O}(0.584 \mathrm{~g}, 2 \mathrm{mmol})$ in 15 $\mathrm{mL}$ of distilled water was added to the solution. The resulting solution was stirred and heated at $60{ }^{\circ} \mathrm{C}$ until a greenish precipitate begins to form, when there was complete precipitation, the mixture was cooled to room temperature. The greenish precipitate was filtered washed with mixture of ethanol/water and dried at room temperature. Green powder was obtained.

Yield: $70 \%$, M.Wt $=435.5$, m.p $>300{ }^{\circ} \mathrm{C}$, Anal. Calcd. $\left(\mathrm{C}_{12} \mathrm{H}_{14} \mathrm{~N}_{4} 0_{9} \mathrm{~S} \mathrm{Cu}\right): \mathrm{C} 31.75 ; \mathrm{H}$ 2.65; N 12.35; Cu 14.00 Found: C 31.64; H 2.54; N 12. 46; Cu 13.66. IR (KBr, $\left.\mathrm{cm}^{-}{ }^{1}\right) 3270$ 159914971436 1291, 1143, 1072, 1043, 820, 720, 619, 560. MS (Positive Cl-methane): M/z (Relative intensity): 97 (70), 123 (38), 156 (29), 177 (17), 249 (100), 310 (5), 336 (4), 379 (3).

\section{Compound 4: $\left[\mathrm{Cu}(\mathrm{DAP})_{2} \mathrm{Cl}_{2}\right]\left(\mathrm{H}_{2} \mathrm{O}\right)\left(\mathrm{CH}_{3} \mathrm{CO}\right)_{2}$}

$0.992 \mathrm{~g}$, (4 mmol) of 4, 4-diaminodiphenylsulphone was dissolved in $15 \mathrm{~mL}$ of acetone, $0.68 \mathrm{~g}(4 \mathrm{mmol})$ of $\mathrm{CuCl}_{2} \cdot 2 \mathrm{H}_{2} \mathrm{O}$ in $15 \mathrm{~mL}$ acetone was added to the above ligand solution. The greenish-yellow solution was stirred continuously for 10 hours at room temperature. A greenish-yellow precipitate was filtered, washed with acetone and dried at room temperature. A greenish yellow powder was obtained.

Yield: $72 \%$, m.p $>300{ }^{0} \mathrm{C}^{\prime} \mathrm{M}$. wt $=734.5$, Anal. Calcd. $\left(\mathrm{C}_{28} \mathrm{H}_{32} \mathrm{~N}_{4} 0_{7} \mathrm{~S} 2 \mathrm{Cl}_{2} \mathrm{Cu}\right): \mathrm{C}$ 45.75; H 4.35; N 7.62; $\mathrm{Cu} 8.65$. Found: $\mathrm{Cu} 45.92, \mathrm{H} \mathrm{4.48;} \mathrm{N} \mathrm{7.98;} \mathrm{Cu}$ 8.40. IR (KBr, cm$\left.{ }^{-1}\right)$ 3473, 3303, 3229, 3118, 1626, 1597, 1568, 1430, 1314, 1153, 1069, 830, 720, 648, 551. UV-Vis (DMSO) $\lambda_{\mathrm{nm}} ; 278,335,830$.

\section{Compound 5: $\left.\mathrm{Cu}(\mathrm{DAP})_{2} \mathrm{Cl}_{2}\right]\left(\mathrm{H}_{2} \mathrm{O}\right)\left(\mathrm{CH}_{3} \mathrm{COOC}_{2} \mathrm{H}_{5}\right)$}

$0.992 \mathrm{~g} \mathrm{(4} \mathrm{mmol)} \mathrm{of} \mathrm{4,} \mathrm{4-diaminodiphenylsulphone} \mathrm{was} \mathrm{dissolved} \mathrm{in} 20 \mathrm{~mL}$ of ethyl acetate, $0.680 \mathrm{~g}(4 \mathrm{mmol})$ of $\mathrm{CuCl}_{2} \cdot 2 \mathrm{H}_{2} \mathrm{O}$ in $15 \mathrm{~mL}$ methanol was added to the above ligand solution. The greenish solution was stirred continuously for 24 hours at room temperature. Dark precipitate obtained was filtered, washed with ethyl acetate/ methanol mixture and dried at room temperature. Dark powder was obtained. 
Yield, 68\% m.p $>300{ }^{0} \mathrm{C}$, M.wt $=736.5$, Anal. Calcd. for $\left(\mathrm{C}_{28} \mathrm{H}_{34} \mathrm{~N}_{4} \mathrm{O}_{7} \mathrm{~S}_{2} \mathrm{CuCl}_{2}\right): \mathrm{C}$ 45.62; H 4.62; N 7.60; Cu 8.62. Found: C 45.53; H 4.78, N 7.72 Cu 8.74. IR $\left(\mathrm{KBr}, \mathrm{cm}^{-1}\right)$ : 3444, 3303, 3230, 3120, 1631, 1598, 1491, 1537, 1331, 1153, 1068, 830, 649, 573, 551, 521 UV - Vis (DMSO) $\lambda_{\text {nm }}: 278,335,889$.

\section{Antimicrobial activities}

The antibacterial activities of the ligand and metal complexes were carried out using well diffusion method described by previous workers ${ }^{11}$. The nutrient agar medium (Peptone beef extract $\mathrm{NaCl}$ and agar-agar) and $5 \mathrm{~mm}$ diameter paper disc (Whatman No.1) were used. The compounds were dissolved in DMSO at 50 and $100 \mathrm{ppm}$ concentration. The filters papers disc were soaked in different solution of the compounds, dried and then placed in the Petridishes previously seeded with the test organisms (Escherichia coli, Staphylococcus aureus and Klebsiella pneumonia). The plates were incubated for $24-30$ hours at $37{ }^{\circ} \mathrm{C}$ and the inhibition zone around each disc was measured in mm using Zone reader. The average zone of inhibition in millimeter was determined from the readings taken in triplicate. DMSO was used as control.

\section{In-vivo antimalarial activity}

Plasmodium berghei and mice were collected from IMRAT, University of Ibadan, Ibadan Nigeria. Mice for the experiment were infected as described by previous worker ${ }^{3}$. Thirty Swiss mice (male) were divided into groups of five animals each and kept in cages fed with mice cubes and water ad libitum.

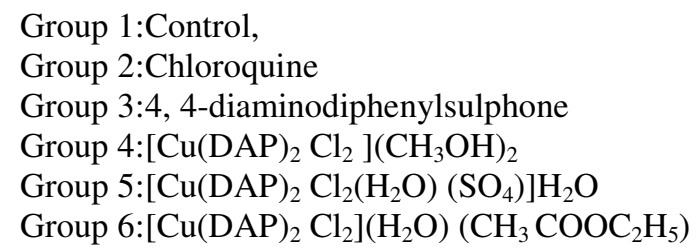

The mice in each group were marked for easy identification. The mice received $0.2 \mathrm{~mL}$ of $1 \times 10^{6}$ parasitized erythrocyctes suspended in buffered physiological saline ( $\mathrm{pH} 7.4$ ) inoculated intravenously. The mice were left for 4 days; their levels of parasitaemias were monitored daily by counting parasites in blood smear, fixed with $70 \%$ methanol and giemsa stained. The slides were then rinsed and allowed to dry. The slides were viewed under the microscope with magnification of 100 . The level of parasitaemia was then determined by counting the number of infected erythrocytes/1000 erythrocyctes on tail blood smears stained with giemsa. 1 ppm solution of each of the ligands and complexes was prepared. 0.4 $\mathrm{mL}$ of each of the solution was injected daily into the mice in each group from day 0 to day 3 of infection. Levels of parasitaemia were determined on day 4. Only physiological saline solution was given to the control animals. The results were expressed as the percentage of infected cells or inhibition of parasitaemia calculated from the equation.

$$
\% \text { inhibition }=100-\frac{\text { Estimated no of infected parasitaemia treated with compounds }}{\text { Estimated no of infected parasitaemia treated with no compounds }}
$$

\section{Toxicological Study}

\section{Experimental animal and drug administration}

A total of 30 male albino rats of average body weight $150 \mathrm{~g}$ were obtained from Biochemistry Department of University of Ilorin, Ilorin. The rats were fed for 2 weeks prior to their usage. The rats were divided into 5 groups (6 rats each). Animals in Group A serve 
as the control and received DMSO, whereas group B were respectively administered with 4, 4-diaminodiphenylsulphone, while groups $\mathrm{C}, \mathrm{D}$ and $\mathrm{E}$ were administered accordingly with $\left[\mathrm{Cu}(\mathrm{DAP}) \mathrm{Cl}_{2}\right]\left(\mathrm{CH}_{3} \mathrm{OH}\right)_{2},\left[\mathrm{Cu}(\mathrm{DAP})\left(\mathrm{H}_{2} \mathrm{O}\right)\left(\mathrm{SO}_{4}\right)\right] \mathrm{H}_{2} \mathrm{O},\left[\mathrm{Cu}(\mathrm{DAP})_{2} \mathrm{Cl}_{2}\right] \mathrm{H}_{2} \mathrm{O}\left(\mathrm{CH}_{3} \mathrm{COOC}_{2} \mathrm{H}_{5}\right)$. The drug solution $\left(1 \mathrm{~cm}^{3}\right)$ prepared with DMSO were administered orally to the rats two times daily for five days at dosage level of $0.122 \mathrm{mg} / 150 \mathrm{~g}$. The control was given only DMSO.

\section{Preparation of serum and tissue homogenates}

The rats were sacrificed 24 hours after the last day of administration of drugs by anaesthetizing them in a glass jar containing cotton wool soaked in chloroform. The blood was collected into clean labeled sample bottles and allowed to coagulate. They were then centrifuged and the serum pipetted out for analysis. The homogenates of the liver, kidney, heart were prepared in ice cold $0.25 \mathrm{M}$ sucrose solution to give a final volume of five times the original tissue weight $(1.5 \mathrm{~W}: \mathrm{V})$. The homogenates were kept in well labeled container and stored in the freezer before being used for analysis. The activities of alkaline phosphatase concentration in the serum and homogenates (liver, kidney and heart) were estimated using the reported method ${ }^{12}$.

\section{Results and Discussion}

Different copper salts were used to synthesis three complexes, with the intention of establishing the effect of varying the counter anion on the composition and characteristic of complexes. The colours of the complexes varied from Army Green to Deep Green. All the complexes were obtained as powder except $\left[\mathrm{Cu}(\mathrm{DAP}) \mathrm{Cl}_{2}\right]\left(\mathrm{CH}_{3} \mathrm{OH}\right)_{2}$ complex, which was microcrystalline. The effect of varying reaction medium (solvent) was also established. Two different complexes were obtained from the reactions of $\mathrm{CuCl}_{2} 2 \mathrm{H}_{2} \mathrm{O}$ and 4,4- diaminodiphenylsulphone in ethyl acetate $\left[\mathrm{Cu}(\mathrm{DAP})_{2} \mathrm{Cl}_{2}\right]\left(\mathrm{H}_{2} \mathrm{O}\right)\left(\mathrm{CH}_{3} \mathrm{COOC}_{2} \mathrm{H}_{5}\right)$ and $\mathrm{CuCl}_{2} 2 \mathrm{H}_{2} \mathrm{O}$ and 4, 4-diaminodiphenylsulphone in acetone $\left[\mathrm{Cu}(\mathrm{DAP})_{2} \mathrm{Cl}_{2}\right]\left(\mathrm{H}_{2} \mathrm{O}\right)\left(\mathrm{CH}_{3} \mathrm{CO}\right)_{2}$. $\mathrm{Cu}$ (II) 4, 4-diaminodiphenylsulphone complex prepared from ethyl acetate was black in colour while the one synthesized with acetone was dirty yellow in colour. The complexes were isolated, characterized by elemental analysis UV-visible, IR Spectroscopy and conductivity measurement. $\left[\mathrm{Cu}(\mathrm{DAP})_{2} \mathrm{Cl}_{2}\right]\left(\mathrm{CH}_{3} \mathrm{OH}\right)_{2}$ and $\left.\left[\mathrm{Cu}(\mathrm{DAP})_{2} \mathrm{Cl}_{2}\right)\right]$ $\left.\left(\mathrm{H}_{2} \mathrm{O}\right)\left(\mathrm{SO}_{4}\right)\right] \mathrm{H}_{2} \mathrm{O}$ were further characterized by ${ }^{1} \mathrm{H} \mathrm{NMR}$. [Cu $\left.(\mathrm{DAP})\left(\mathrm{NO}_{3}\right)\left(\mathrm{H}_{2} \mathrm{O}\right)\right] \mathrm{NO}_{3}$ was also characterized by mass spectroscopy. The elemental analysis agreed with 1:1 and 1:2 metal ligand stoichiometries for the complexes. They are non electrolyte as revealed by conductivity results. The complexes are insoluble in most organic solvents except $\left[\mathrm{Cu}(\mathrm{DAP})_{2} \mathrm{Cl}_{2}\right]\left(\mathrm{CH}_{3} \mathrm{OH}\right)_{2}$ which was soluble in methanol. All were soluble in dimethylsulfoxide. Chloride ions were determined by means of $\mathrm{AgNO}_{3}$ as corresponding silver salts. There was no precipitation of silver halide, indicating that the chloride ions are inside the coordination sphere of the metal complexes. The free sulphate ions were estimated by means of $\mathrm{BaCl}_{2}$ respectively as corresponding barium salts $^{13}$. Test for sulphate ion was also negative this may be due to coordination of the ion to the metal as in $\left.\left.\left[\mathrm{Cu}(\mathrm{DAP})_{2} \mathrm{Cl}_{2}\right)\right]\left(\mathrm{H}_{2} \mathrm{O}\right)\left(\mathrm{SO}_{4}\right)\right] \mathrm{H}_{2} \mathrm{O}$. Different colours obtained for [Cu $(\mathrm{DAP})_{2}$ $\left.\mathrm{Cl}_{2}\right]\left(\mathrm{H}_{2} \mathrm{O}\right)\left(\mathrm{CH}_{3} \mathrm{COOC}_{2} \mathrm{H}_{5}\right)$ (Black), [Cu(DAP $\left.)_{2} \mathrm{Cl}_{2}\right]\left(\mathrm{CH}_{3} \mathrm{OH}\right)_{2}$ (Army Green), [Cu (DAP) ${ }_{2} \mathrm{Cl}_{2}$ ] $\left(\mathrm{H}_{2} \mathrm{O}\right)\left(\mathrm{CH}_{3} \mathrm{CO}\right)_{2}$ (Dirty yellow) may be due to solvent molecules presence outside the coordination sphere of each complex as revealed by elemental analysis results.

\section{Infrared spectra}

Infra red spectra assignments of 4,4-diaminodiphenylsulphone and the complexes are shown in Table 1. Comparing the main IR frequencies of copper complexes with that of 4, 4-diaminodiphenylsulphone ligand the following deductions were made. The infra-red spectrum of 4,4-diaminodiphenylsulphone showed four prominent peaks at 34553396,3337 and $3238 \mathrm{~cm}^{-1}$ assigned to $\mathrm{NH}_{2}$ group due to $v_{\text {asy }}(\mathrm{N}-\mathrm{H})$ and $v_{\text {sym }}(\mathrm{N}-\mathrm{H})$. Two of these peaks (3357 and $3258 \mathrm{~cm}^{-1}$ ) present in the ligand were shifted significantly to lower frequencies of 
3231 and $3140 \mathrm{~cm}^{-1}$ in $\left[\mathrm{Cu}(\mathrm{DAP})_{2} \mathrm{Cl}_{2}\right]\left(\mathrm{H}_{2} \mathrm{O}\right)\left(\mathrm{CH}_{3} \mathrm{CO}\right)_{2}, 3230,3120 \mathrm{~cm}^{-1}$ in $[\mathrm{Cu}$ (DAP) $\left.)_{2} \mathrm{Cl}_{2}\right]\left(\mathrm{H}_{2} \mathrm{O}\right)\left(\mathrm{CH}_{3} \mathrm{COOC}_{2} \mathrm{H}_{5}\right)$ complexes. This is probably due to coordination of the metal ion to one of the terminal $\mathrm{NH}_{2}$ groups of the ligand. This is in agreement to the finding of previous workers ${ }^{14}$. The authors stated that the difference between ${ }^{*} v\left(\mathrm{NH}_{2}\right)$ of the metal drug compounds and those of parent ligand being $v\left(\mathrm{NH}_{2}\right)=v \mathrm{~s}+$ vas/ 2 gives information about the involvement of the $\mathrm{NH}_{2}$ in the metal complexation.

According to these authors, if the value of $v^{*}$ free ligand $-v^{*}$ coordinated ligand is $>+70$, the amino moiety is involved in coordination for example $\left[\mathrm{Cu}(\mathrm{DAP})_{2} \mathrm{Cl}_{2}\right]\left(\mathrm{CH}_{3} \mathrm{OH}\right)_{2}$ complex, the value is calculated to be 93 . These four prominent peaks became broad, strong and centered at $3270 \mathrm{~cm}^{-1}$ in $\left[\mathrm{Cu}(\mathrm{DAP})\left(\mathrm{NO}_{3}\right)\left(\mathrm{H}_{2} \mathrm{O}\right)\right] \mathrm{NO}_{3}$ and at $3455 \mathrm{~cm}^{-1}$ in $\left.\left.\left(\mathrm{Cu}(\mathrm{DAP})_{2} \mathrm{Cl}_{2}\right)\right]\left(\mathrm{H}_{2} \mathrm{O}\right)\left(\mathrm{SO}_{4}\right)\right] \mathrm{H}_{2} \mathrm{O}$. These can be attributed to the overlapping of $\mathrm{vNH}_{2}$ with the coordinated water in the two complexes indicating that $\mathrm{NH}_{2}$ group was involved in coordination. Sharp and intense bands at $1338 \mathrm{~cm}^{-1}$ and $1146 \mathrm{~cm}^{-1}$ which were the asymmetric and symmetric $\mathrm{v}\left(\mathrm{SO}_{2}\right)$ modes respectively in the ligand were modified to the extent that one of the peaks $1338 \mathrm{~cm}^{-1}$ disappeared in $\left.\left.\left(\mathrm{Cu}(\mathrm{DAP})_{2} \mathrm{Cl}_{2}\right)\right]\left(\mathrm{H}_{2} \mathrm{O}\right)\left(\mathrm{SO}_{4}\right)\right] \mathrm{H}_{2} \mathrm{O},\left[\mathrm{Cu}(\mathrm{DAP})\left(\mathrm{NO}_{3}\right)\left(\mathrm{H}_{2} \mathrm{O}\right)\right] \mathrm{NO}_{3}$. This is due to the chelation of $\mathrm{Cu}$ (II) through one oxygen atom of $\mathrm{SO}_{2}$ group. This mode of coordination has also been found in a platinum sulfadiazine derivative ${ }^{15}$. In addition the negative shift of $v C-S\left(648 \mathrm{~cm}^{-1}\right)$ in the ligand to $619 \mathrm{~cm}^{-1}$ in the complex reinforces this statement ${ }^{16}$. There are no changes in both symmetrical and asymmetrical stretching frequencies of $\mathrm{SO}_{2}$ in $\left(\mathrm{Cu}(\mathrm{DAP})_{2} \mathrm{Cl}_{2}\right]\left(\mathrm{CH}_{3} \mathrm{OH}\right)_{2}$, $\left.\left[\mathrm{Cu}(\mathrm{DAP})_{2} \mathrm{Cl}_{2}\right]\left(\mathrm{H}_{2} \mathrm{O}\right)\left(\mathrm{CH}_{3} \mathrm{CO}\right)_{2}, \mathrm{Cu}(\mathrm{DAP})_{2} \mathrm{Cl}_{2}\right]\left(\mathrm{H}_{2} \mathrm{O}\right)\left(\mathrm{CH}_{3} \mathrm{COOC}_{2} \mathrm{H}_{5}\right)$ complexes due to noninvolvement of $\mathrm{SO}_{2}$ in the coordination. The coordinated water bind between the water molecules and the cation resulted in the appearance of vibrational band $720 \mathrm{~cm}^{-1}\left(\mathrm{vM}-\mathrm{OH}_{2}\right)$ in the two complexes ${ }^{17}$. However some new bands with medium to weak interaction appeared at $558 \mathrm{~cm}^{-1}$ in all complexes which are tentatively assigned to $v(\mathrm{M}-\mathrm{N})$ modes.

Table 1. Infra-red Spectra of 4, 4-diaminodiphenylsulphone and its complexes.

\begin{tabular}{|c|c|c|c|c|c|c|c|}
\hline Complexes / ligand & $\mathrm{vNH}_{2}$ & $\underset{\mathscr{C}}{>}$ & 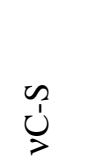 & $\vec{Z}_{0}^{N}$ & $\bigcup_{>}^{\|}$ & $\begin{array}{l}\text { Ô } \\
\stackrel{1}{0} \\
\sum_{>}^{1}\end{array}$ & $\sum_{>}^{Z_{1}}$ \\
\hline Dapsone & $\begin{array}{l}v_{\text {asy }} 3455 \mathrm{~s}, 3396 \mathrm{~m} \\
v_{\text {sym }} 3337 \mathrm{~m}, 3238 \mathrm{~m}\end{array}$ & $\begin{array}{l}1338 \mathrm{w} \\
1146 \mathrm{~s}\end{array}$ & $648 w$ & $1590 \mathrm{~s}$ & $1630 \mathrm{~s}$ & - & - \\
\hline$\left[\mathrm{Cu}(\mathrm{DAP})_{2} \mathrm{Cl}_{2}\right]\left(\mathrm{CH}_{3} \mathrm{OH}\right)_{2}$ & $\begin{array}{l}v_{\text {asy }} 3443 \mathrm{~s}, 3360 \mathrm{~s} \\
v_{\text {sym }} 3231 \mathrm{~m}, 3140 \mathrm{~m}\end{array}$ & $\begin{array}{l}1340 \mathrm{w} \\
1145 \mathrm{~s}\end{array}$ & $648 w$ & $1594 \mathrm{~s}$ & $1632 \mathrm{~s}$ & - & $550 \mathrm{~s}$ \\
\hline$\left[\mathrm{Cu}(\mathrm{DAP})\left(\mathrm{NO}_{3}\right) \mathrm{H}_{2} \mathrm{O}\right] \mathrm{NO}_{3}$ & $3270 \mathrm{~m}$ & $1143 m$ & $619 \mathrm{~m}$ & $1599 \mathrm{~s}$ & - & $720 \mathrm{~s}$ & $560 \mathrm{~s}$ \\
\hline$\left[\mathrm{Cu}(\mathrm{DAP})\left(\mathrm{H}_{2} \mathrm{O}\right) \mathrm{SO}_{4}\right] \mathrm{H}_{2} \mathrm{O}$ & $3455 s$ & $1144 s$ & $619 \mathrm{~m}$ & $1596 \mathrm{~s}$ & $1628 \mathrm{~m}$ & $720 w$ & $559 \mathrm{~s}$ \\
\hline $\begin{array}{l}{\left[\mathrm{Cu}(\mathrm{DAP})_{2} \mathrm{CI}_{2}\right]\left(\mathrm{CH}_{3} \mathrm{CO}_{2}-\right.} \\
\left.\mathrm{C}_{2} \mathrm{H}_{5}\right)\left(\mathrm{H}_{2} \mathrm{O}\right)\end{array}$ & $\begin{array}{l}v_{\text {asy }} 3444 \mathrm{~s}, 3303 \mathrm{~m} \\
v_{\text {sym }} 3230 \mathrm{~s}, 3120 \mathrm{vw}\end{array}$ & $\begin{array}{l}1331 \mathrm{~s} \\
1153 \mathrm{~s}\end{array}$ & $648 \mathrm{~m}$ & $1597 \mathrm{~m}$ & $1631 \mathrm{~m}$ & & $551 \mathrm{~m}$ \\
\hline$\left[\mathrm{Cu}(\mathrm{DAP})_{2}\right] \mathrm{Cl}_{2}\left(\mathrm{CH}_{3} \mathrm{CO}\right)_{2} \mathrm{H}_{2} \mathrm{O}$ & $\begin{array}{l}v_{\text {asy }} 3473 \mathrm{br}, 3303 \mathrm{~m} \\
v_{\text {sym }} 3229 \mathrm{~m}, 3118 \mathrm{~m}\end{array}$ & $\begin{array}{l}1314 \mathrm{~s} \\
1153 \mathrm{~s}\end{array}$ & $648 \mathrm{~m}$ & $1597 \mathrm{~s}$ & $1626 w$ & & $551 \mathrm{~s}$ \\
\hline
\end{tabular}

\section{Electronic Spectra}

Comparison of the electronic spectra (in DMSO) of the 4, 4 - diaminodiphenylsulphone and its complexes shows that bands at 266nm and 301nm assigned to $\pi-\pi^{*}$ and $n-\pi^{*}$ of the conjugated system of the ligand exhibited red shift in the absorption bands of the complexes due to complexation. Single absorption peaks around 700-900 $\mathrm{mm}$ due to d-d transition is assigned as $2 \mathrm{~T}_{2}$ - ${ }^{2} \mathrm{E}$ due to Jahn Teller distortion. ${ }^{18}$ Tetrahedral $\mathrm{Cu}(\mathrm{II})$ complexes often give broad bands resulting from several overlapping bands or where the bands are resolved up to three close bands. 
This clearly indicates a tetrahedral environment around $\mathrm{Cu}$ (II) ion for the five complexes. The absorption spectra of copper(II) complexes are similar to those of copper(II) Quinine complexes. This is evidence that supports the binding of nitrogen atom to copper (II) ion.

\section{${ }^{1}$ HNMR Spectroscopy}

The 'HNMR spectra and the assignments for 4,4-diaminodiphenylsulphone and its complexes are shown in Figure 1, Table 2 and Figures 2-4.<smiles>Nc1ccc(S(=O)(=O)c2ccc(N)cc2)cc1</smiles>

Figure 1. Molecular Structure of 4, 4-diaminodiphenylsulphone.

Table 2. ${ }^{1} \mathrm{HNMR}$ for $\delta(\mathrm{DAP})$ and its complexes.

\begin{tabular}{llcc}
\hline Assignment & DAP & {$\left[\mathrm{Cu}(\mathrm{DAP})\left(\mathrm{H}_{2} \mathrm{O}\right)\left(\mathrm{SO}_{4}\right)\right] \mathrm{H}_{2} \mathrm{O}$} & {$\left[\mathrm{Cu}(\mathrm{DAP})_{2} \mathrm{Cl}_{2}\right]\left(\mathrm{CH}_{3} \mathrm{OH}\right)_{2}$} \\
\hline $\mathrm{H}(3 \mathrm{~b}), \mathrm{H}(5 \mathrm{~b}) / \mathrm{H}(3 \mathrm{a}), \mathrm{H}(5 \mathrm{a})$ & 7.55 & $7.40-7.45$ & 7.6 \\
$\mathrm{H}(6 \mathrm{~b}), \mathrm{H}(2 \mathrm{~b}) / \mathrm{H}(6 \mathrm{a}), \mathrm{H}(2 \mathrm{a})$ & 6.5 & 6.40 & 6.5 \\
$2 \mathrm{H}, \mathrm{NH}_{2}$ & 6.01 & - & 5.85 \\
\hline
\end{tabular}

The peak at $\delta 6.01$ in the ligand due to proton of $\mathrm{NH}_{2}$ disappeared in $\left.\mathrm{Cu}(\mathrm{DAP})_{2} \mathrm{Cl}_{2}\right)$ ] $\left.\left(\mathrm{H}_{2} \mathrm{O}\right)\left(\mathrm{SO}_{4}\right)\right] \mathrm{H}_{2} \mathrm{O}$ and slightly shifted to $5.85 \mathrm{ppm}$ in $\left[\mathrm{Cu}(\mathrm{DAP})_{2} \mathrm{Cl}_{2}\right]\left(\mathrm{CH}_{3} \mathrm{OH}\right)_{2}$ as a consequences of coordination of one of the $\mathrm{NH}_{2}$ group with copper ion. Furthermore another evidence of coordination at the site is that the $\delta(7.33), \mathrm{H} 3 \mathrm{~b}, \mathrm{H}(5 \mathrm{~b}) / \mathrm{H}(3 \mathrm{a}) \mathrm{H}(5 \mathrm{a})$ slightly shifted to 7.40-7.45 in $\left[\mathrm{Cu}(\mathrm{DAP})_{2} \mathrm{Cl}_{2}\right]\left(\mathrm{CH}_{3} \mathrm{OH}\right)_{2}$. The upfield shift of $\mathrm{H}(6 \mathrm{~b}), \mathrm{H}(2 \mathrm{~b}) /$ $\mathrm{H}(6 \mathrm{a}), 2 \mathrm{a}$, of about $0.10 \mathrm{ppm}$ substantiate the involvement of $\mathrm{SO}_{2}$ in the coordination for $\left.\left.\left.[\mathrm{CuDAP})_{2} \mathrm{Cl}_{2}\right)\right]\left(\mathrm{H}_{2} \mathrm{O}\right)\left(\mathrm{SO}_{4}\right)\right] \mathrm{H}_{2} \mathrm{O}$

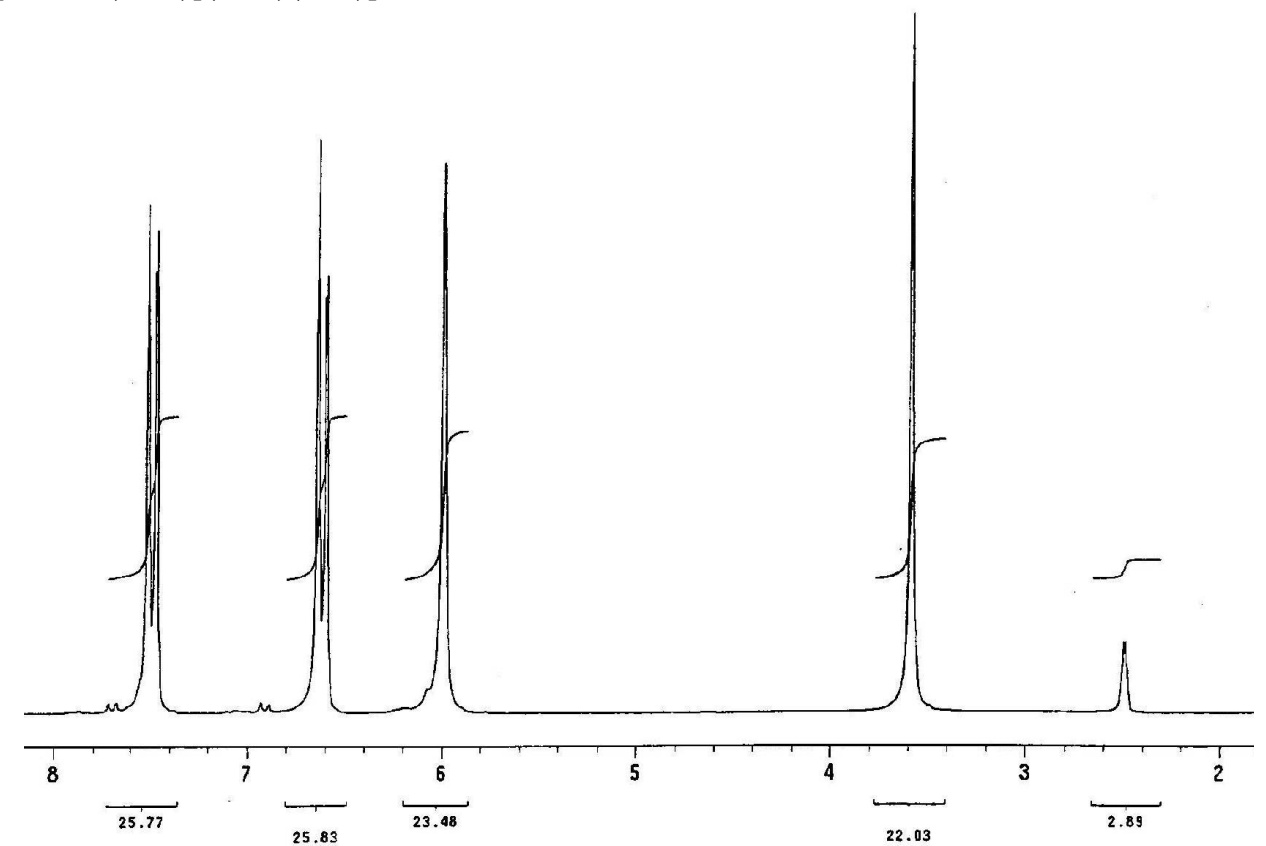

Figure 2. ${ }^{1}$ HNMR Spectrum of 4, 4-diaminodiphenylsulphone. 
A. C. TELLA et al.

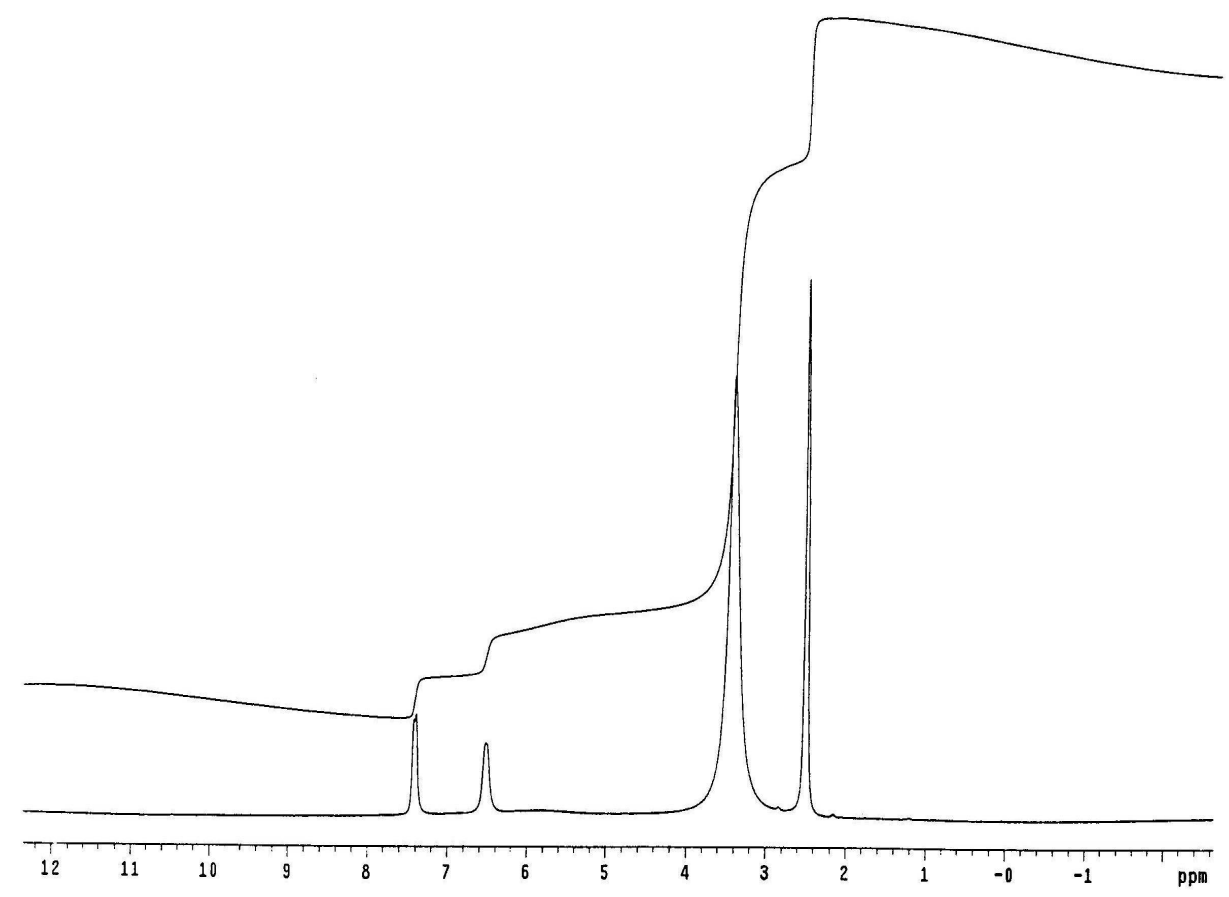

Figure 3. ${ }^{1} \mathrm{HNMR}$ Spectra of $\left[\mathrm{Cu}(\mathrm{DAP})_{2} \mathrm{Cl}_{2}\right]\left(\mathrm{CH}_{3} \mathrm{OH}\right)_{2}$.

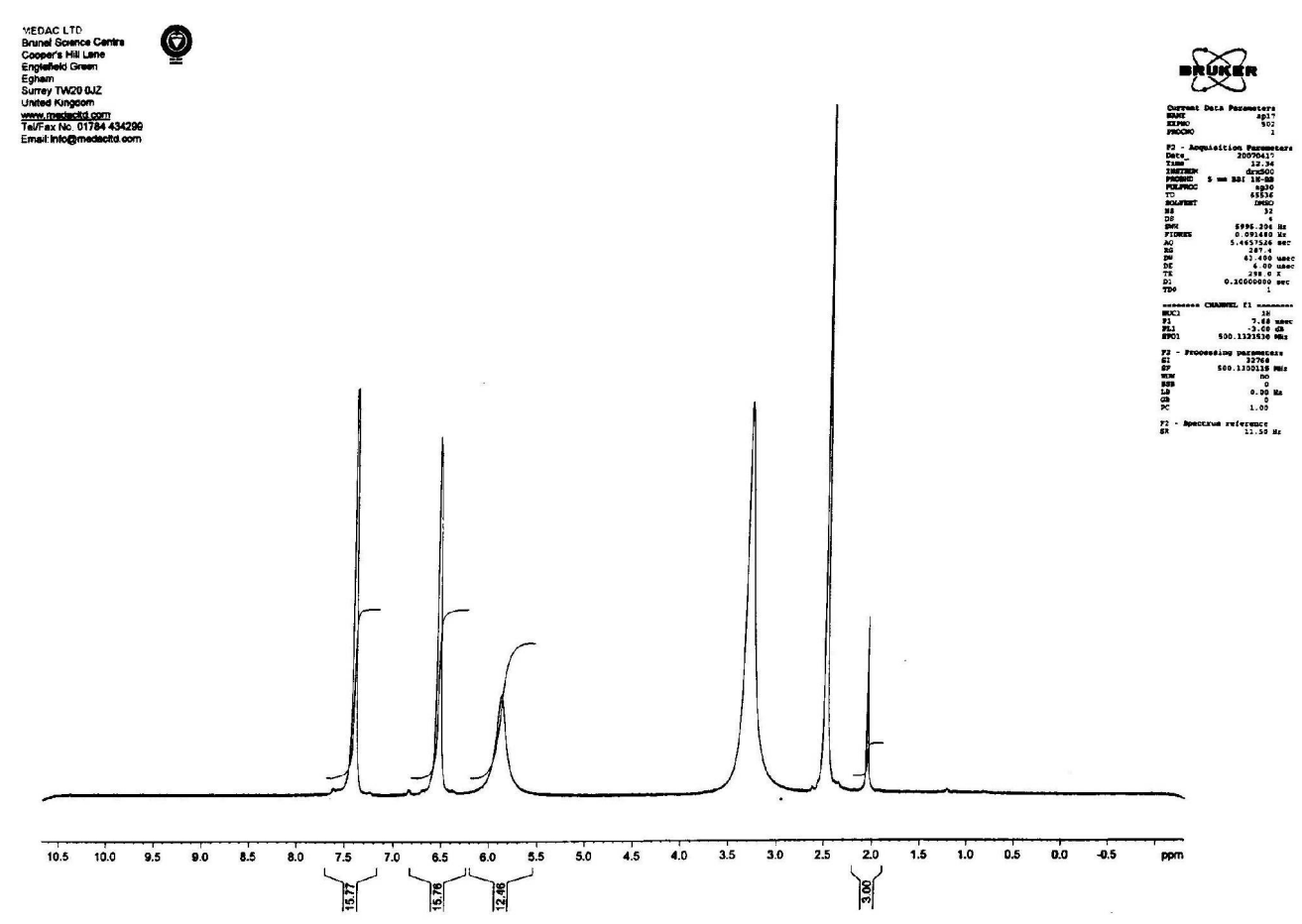

Figure 4. ${ }^{1} \mathrm{HNMR}$ Spectrum of $\left[\mathrm{Cu}(\mathrm{DAP})\left(\mathrm{H}_{2} \mathrm{O}\right)\left(\mathrm{SO}_{4}\right)\right] \mathrm{H}_{2} \mathrm{O}$ 


\section{Mass spectroscopy}

The mass spectral relevant $\mathrm{m} / \mathrm{z}$ ratios and tentative assignments of $\left[\mathrm{Cu}(\mathrm{DAP})\left(\mathrm{NO}_{3}\right)\left(\mathrm{H}_{2} \mathrm{O}\right)\right] \mathrm{NO}_{3}$ are shown in Table 3 and Figure 5 These changes in position of the proton may also be due to increase in electronic change over the two rings. As could be expected that the most significant shifts occurred in the resonance of the protons linked to the carbon closest to the donor atoms ${ }^{19}$

Table 3. Mass Spectra Assignments for $\left[\mathrm{Cu}(\mathrm{DAP})\left(\mathrm{NO}_{3}\right)\left(\mathrm{H}_{2} \mathrm{O}\right)\right] \mathrm{NO}_{3}$

\begin{tabular}{ccccccc}
\hline $\mathrm{m} / \mathrm{z}$ & Relative intensity, \% & Assignment \\
\hline 249 & 100 & 4 & \\
156 & 28 & \\
123 & 37 &
\end{tabular}

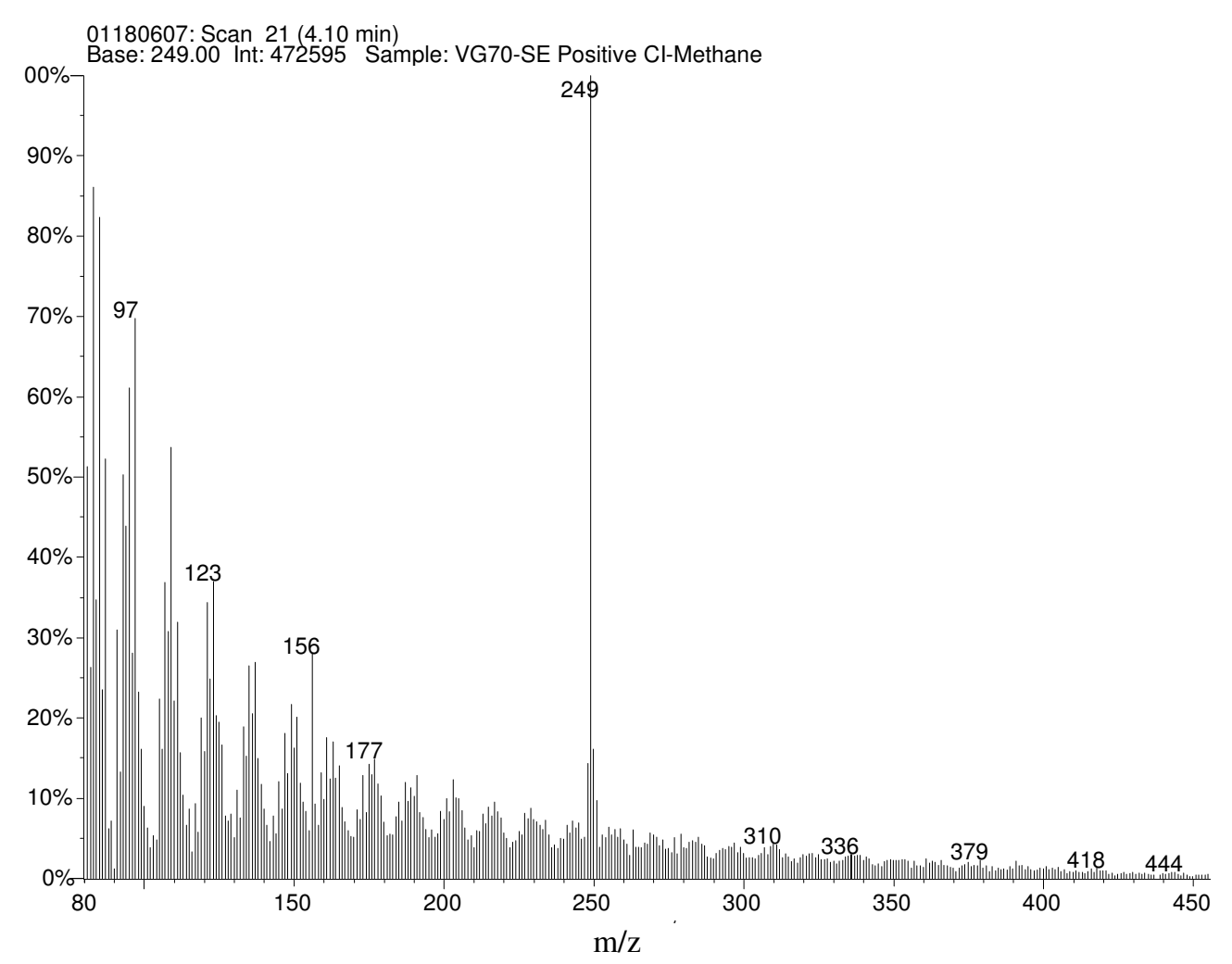

Figure 5. Mass Spectra of $\left[\mathrm{Cu}(\mathrm{DAP})\left(\mathrm{NO}_{3}\right)\left(\mathrm{H}_{2} \mathrm{O}\right)\right] \mathrm{NO}_{3}$ 
The peak at $\mathrm{m} / \mathrm{z} 249$ is assigned to 4, 4-diaminodiphenylsulphone $\left(\mathrm{C}_{12} \mathrm{H}_{12} \mathrm{~N}_{2} \mathrm{O}_{2}\right)$. The peak observed at $\mathrm{m} / \mathrm{z} 310$ corresponds to $\mathrm{Cu}\left(\mathrm{C}_{12} \mathrm{H}_{12} \mathrm{~N}_{2} \mathrm{O}_{2}\right)$. The peak observed at $\mathrm{m} / \mathrm{z} 310$ corresponds to $\mathrm{Cu}\left(\mathrm{C}_{12} \mathrm{H}_{12} \mathrm{~N}_{2} \mathrm{O}_{2}\right)^{+}$indicating water molecules has been lost from the complex. Lost of $\mathrm{C}_{6} \mathrm{H}_{6} \mathrm{~N}$ from $\mathrm{m} / \mathrm{z} 249$ results in the formation of fragments ion $\mathrm{m} / \mathrm{z} 156$. Intense peaks were observed at $\mathrm{m} / \mathrm{z} 123$ as a result of fragmentation of $\mathrm{m} / \mathrm{z} 156$. Based on these results proposed structures are presented in Figures 5-7.

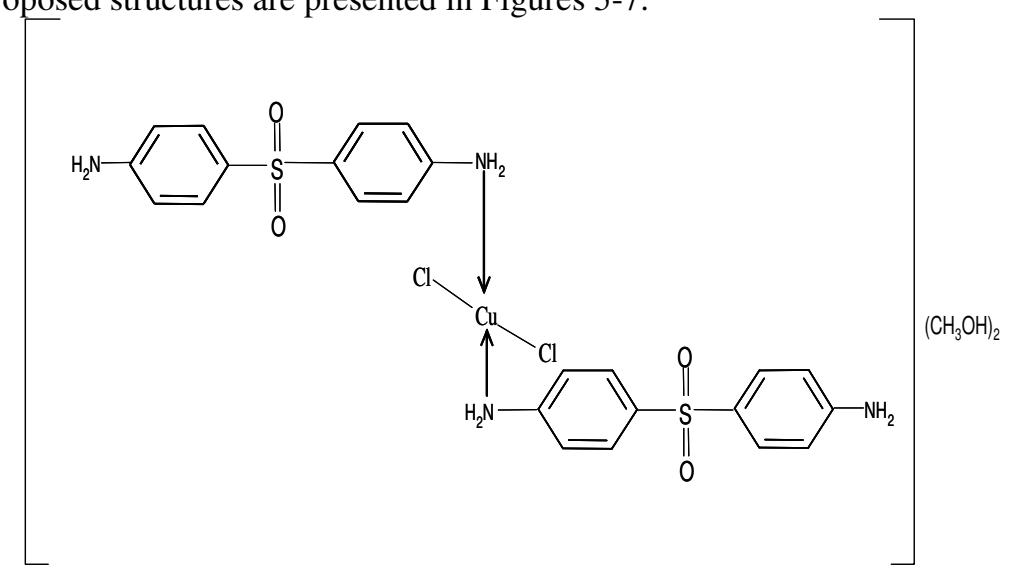

Figure 6. Proposed structure of $\left[\mathrm{Cu}(\mathrm{DAP})_{2} \mathrm{Cl}_{2}\right]\left(\mathrm{CH}_{3} \mathrm{OH}\right)_{2}$

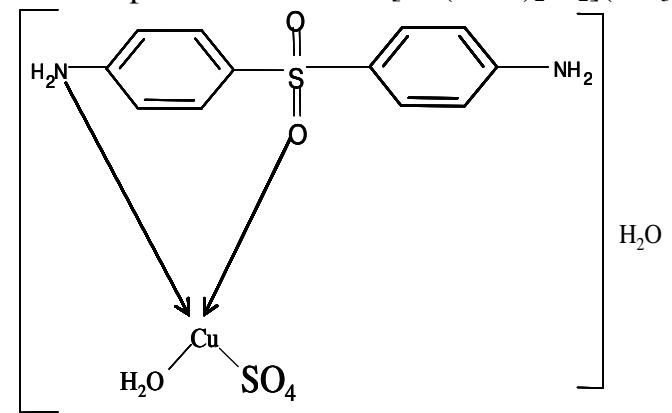

Figure 7. Proposed structure of $\left.\left.\left.\mathrm{Cu}(\mathrm{DAP})_{2} \mathrm{Cl}_{2}\right)\right]\left(\mathrm{H}_{2} \mathrm{O}\right)\left(\mathrm{SO}_{4}\right)\right] \mathrm{H}_{2} \mathrm{O}$.

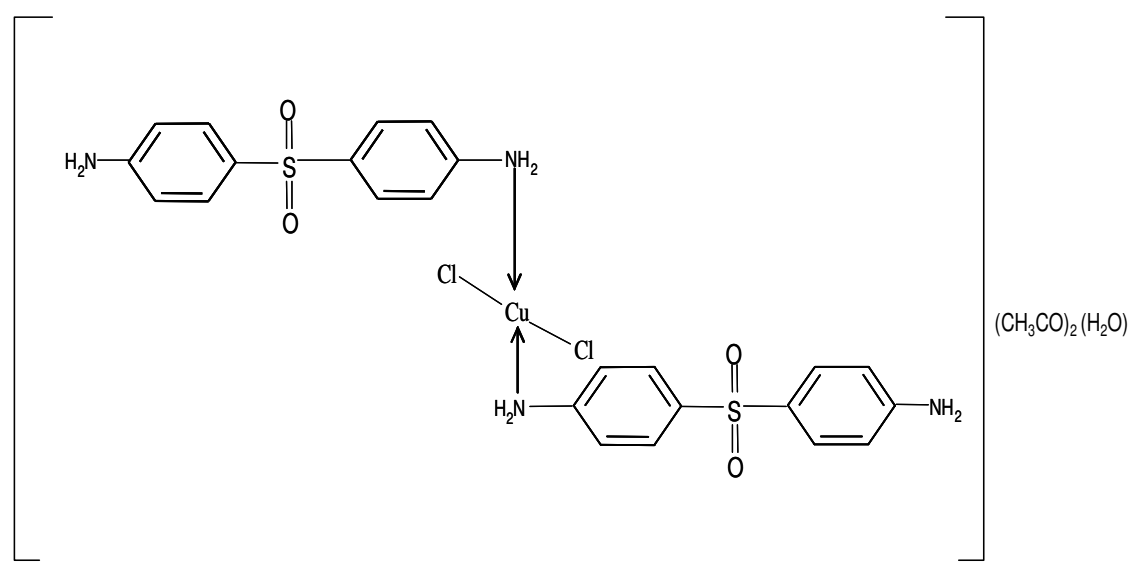

Figure 8. Proposed structure of $\left[\mathrm{Cu}(\mathrm{DAP})_{2} \mathrm{Cl}_{2}\right]\left(\mathrm{H}_{2} \mathrm{O}\right)\left(\mathrm{CH}_{3} \mathrm{CO}\right)_{2}$. 


\section{Biological Studies}

Both the ligand and complexes were screened against gram -positive and gram- negative bacterial in order to determine if the spectrum of the activity of the complexes was changed with respect to ligand. The inhibitory activities of the metal complexes at 50ppm and 100ppm concentration as compared to the free ligands on the bacterial species are revealed in the table. The increase of the zone of inhibition for metal complexes when compared with corresponding ligands as shown in Table 4. is an indication that the metal complexes are able to decrease the population of bacterial species. It is also an indication that the metal complexes are more effective than their corresponding ligand. The results are in agreement with the finding of previous workers ${ }^{20}$. The chelating increases the lipophilic nature of the central atom which subsequently favour its permeation through the lipid layer of the cell membrane ${ }^{21}$. The chelation theory account for the increase activities of the metal complexes. The result shows that most of the compounds posses higher inhibitory activity against the bacterial species at $100 \mathrm{ppm}$ concentration than at $50 \mathrm{ppm}$ concentration. The effects of oral administration of the ligand and the complexes on the liver, kidney and serum of Albino rats are shown in Table 5.

Table 4. Antibacterial Screening Data of 4, 4-diaminodiphenylsulphone and its Complexes.

\begin{tabular}{|c|c|c|c|c|c|c|}
\hline \multirow{2}{*}{ Ligand } & \multicolumn{2}{|c|}{ E. coli } & \multicolumn{2}{|c|}{ S. aureus } & \multicolumn{2}{|c|}{ K.Pneumonia } \\
\hline & $\mathrm{m}$ & 100 & $\mathrm{ppm}$ & $100 \mathrm{p}$ & $\mathrm{ppm}$ & $100 \mathrm{ppm}$ \\
\hline DAP & $15 \pm 1.00^{\mathrm{a}}$ & $20 \pm 1.60^{\mathrm{a}}$ & $25 \pm 1.80^{\mathrm{a}}$ & $27 \pm$ & $18 \pm 1.10^{\mathrm{a}}$ & \\
\hline$[\mathrm{Cu}(\mathrm{DAF}$ & $21+200^{\mathrm{b}}$ & $20 \pm 1.40^{\mathrm{a}}$ & $19 \pm 1.50^{b}$ & $37.5 \pm 1.90^{\mathrm{b}}$ & $21 \pm 1.17^{\mathrm{b}}$ & $22 \pm 1.96^{\mathrm{a}}$ \\
\hline$[\mathrm{Cu}(\mathrm{DAP})($ & $19 \pm 1.12$ & $20 \pm 1.81^{\mathrm{a}}$ & $5 \pm 2.00^{\mathrm{a}}$ & $38 \pm 2.11^{\mathrm{b}}$ & $21 \pm 1.34^{\mathrm{b}}$ & \\
\hline$[\mathrm{Cu}(\mathrm{I}$ & $18 \pm 1.60^{\mathrm{a}, \mathrm{b}}$ & $23 \pm 1.90^{\mathrm{a}}$ & $28 \pm 2.10^{\mathrm{a}}$ & & $20 \pm 1.60^{\mathrm{b}}$ & \\
\hline $\begin{array}{l}\mathrm{Cu}(\mathrm{D} \\
\mathrm{C}_{2} \mathrm{H}_{5}\end{array}$ & $18 \pm 1$ & 2 & $9^{\mathrm{b}}$ & $31 \pm 2.01^{\mathrm{a}}$ & $18 \pm 1.61^{\mathrm{a}}$ & $2.01^{\circ}$ \\
\hline$\left[\mathrm{Cu}(\mathrm{DAP})_{2}\right] \mathrm{Cl}_{2}\left(\mathrm{CH}_{3} \mathrm{CO}\right)_{2} \mathrm{H}_{2} \mathrm{O}$ & $26 \pm 1.82^{\mathrm{c}}$ & $28 \pm 2.11^{\mathrm{b}}$ & $34 \pm 2.16^{\mathrm{c}}$ & $33 \pm 1.99^{\mathrm{b}}$ & $26 \pm 1.91^{\mathrm{c}}$ & $27 \pm 2.11^{\mathrm{b}}$ \\
\hline
\end{tabular}

Table 5. Effects of administration of DAP and its complexes on alkaline phosphate activities of rat organs

\begin{tabular}{llll}
\hline Ligand/Complexes & Kidney (IU/L) & Liver (IU/L) & Serum (IU/L) \\
\hline DAP & $75.20 \pm 6.11^{1}$ & $22.65 \pm 1.17^{\mathrm{h}}$ & $10.38 \pm 0.99^{\mathrm{a}}$ \\
{$\left[\mathrm{Cu}(\mathrm{DAP}) \mathrm{Cl}_{2} \mathrm{CH}_{3} \mathrm{OH}\right)_{2}$} & $86.42 \pm 7.11^{1}$ & $28.62 \pm 1.29^{\mathrm{i}}$ & $10.22 \pm 0.96^{\mathrm{a}}$ \\
{$\left[\mathrm{Cu}(\mathrm{DAP}) \mathrm{SO}_{4}\left(\mathrm{H}_{2} \mathrm{O}\right)\right] \mathrm{H}_{2} \mathrm{O}$} & $94.16 \pm 7.96^{\mathrm{m}}$ & $30.46 \pm 1.38^{\mathrm{i}}$ & $10.84 \pm 0.99^{\mathrm{a}}$ \\
\hline
\end{tabular}

Table 5 presents alkaline phosphatase activities (ALP) in the kidney, liver and serum following administration of the ligand and the complexes. The serum ALP activity showed no significant change $(\mathrm{P}>0.05)$ on comparison with one another and the control after repeated administration of ligand and complexes.

The fact that there was no significant difference in serum ALP activities of 4, 4diaminodiphenylsulphone and its metal complexes compared with control suggests that the integrity of the plasma membrane of the cells in the various tissues might have been adversely affected. This is because ALP is a membrane bound enzyme often used to assess the integrity of the plasma membrane and endoplasmic reticulum and an increase in ALP activity of the serum implies membrane damage to the tissues ${ }^{12}$. Moreover, the observed increase in the ALP activities in the liver and kidney of Albino rats administered with 4, 4diaminodiphenylsulphone complexes suggests an enhancement of the activities of the existing enzymes by the drugs and their metabolites. The increase may also be as a result of 
stress imposed on the tissue by the drugs, which may lead to loss of the enzyme molecule through leakage into intracellular fluid which has not been significantly noticed in the serum. In a bid to offset this stress, the tissue may increase the de novo synthesis of the enzyme, thus accounting for the increase in ALP activities in these tissues ${ }^{23,24}$.

Table 6. Percentage parasitaemia of DAP and its metal complexes

\begin{tabular}{lcccc}
\hline \multicolumn{1}{c}{$\begin{array}{c}\text { Ligand/ } \\
\text { Complexes }\end{array}$} & No & $\begin{array}{c}\text { \%Average } \\
\text { parasitaemia } \\
\text { before } \\
\text { administration }\end{array}$ & $\begin{array}{c}\text { \%Average } \\
\text { parasitaemia } \\
\text { after } \\
\text { administration }\end{array}$ & $\begin{array}{c}\text { Reduction } \\
\text { in } \\
\text { parasitaemia }\end{array}$ \\
\hline $\mathrm{DAP}$ & $\mathrm{B}_{1}$ & 60 & 32 & 42 \\
{$\left[\mathrm{Cu}(\mathrm{DAP})_{2} \mathrm{Cl}_{2} \mathrm{CH}_{3} \mathrm{OH}\right)_{2}$} & $\mathrm{D}_{1}$ & 34 & 19 & 41 \\
$\left(\mathrm{Cu}(\mathrm{DAP})_{2} \mathrm{Cl}_{2}\right]\left(\mathrm{H}_{2} \mathrm{O}\right)\left(\mathrm{CH}_{3} \mathrm{COOC}_{2} \mathrm{H}_{5}\right)$ & $\mathrm{D}_{2}$ & 26 & 16 & 38 \\
{$\left[\mathrm{Cu}(\mathrm{DAP}) \mathrm{SO}_{4}\left(\mathrm{H}_{2} \mathrm{O}\right)\right] \mathrm{H}_{2} \mathrm{O}$} & $\mathrm{D}_{3}$ & 40 & 23 & 40 \\
Chloroquine & $\mathrm{C}$ & 40 & 8 & 68 \\
\hline
\end{tabular}

Antimalarial activities of the complexes investigated using mice infected with Plasmodium berghei showed that the complexes exhibited lower antimalarial activities than DAP and chloroquine. This indicates that coordination of the metal to DAP reduces its antimalarial activities. The $\%$ parasitaemia reduction for $\left[\mathrm{Cu}(\mathrm{DAP})_{2} \mathrm{Cl}_{2} \mathrm{CH}_{3} \mathrm{OH}\right)_{2},(\mathrm{Cu}$ (DAP) $\left.)_{2} \mathrm{Cl}_{2}\right]\left(\mathrm{H}_{2} \mathrm{O}\right)\left(\mathrm{CH}_{3} \mathrm{COOC}_{2} \mathrm{H}_{5}\right),\left[\mathrm{Cu}(\mathrm{DAP}) \mathrm{SO}_{4}\left(\mathrm{H}_{2} \mathrm{O}\right)\right] \mathrm{H}_{2} \mathrm{O}$ are $41 \%, 38 \%$ and $40 \%$. The DAP and metal complexes $\left[\mathrm{Cu}(\mathrm{DAP})_{2} \mathrm{Cl}_{2} \mathrm{CH}_{3} \mathrm{OH}\right)_{2}\left[\mathrm{Cu}(\mathrm{DAP}) \mathrm{SO}_{4}\left(\mathrm{H}_{2} \mathrm{O}\right)\right] \mathrm{H}_{2} \mathrm{O}$ and $\left[\mathrm{Cu}(\mathrm{DAP})\left(\mathrm{NO}_{3}\right)\right.$ $\left.\left(\mathrm{H}_{2} \mathrm{O}\right)\right] \mathrm{NO}_{3}$ were found to be non toxic as revealed from effect of administration of the complexes on ALP activity of kidney, liver and serum of albino rats

\section{Conclusion}

This study has contributed to an effort being made in discovery of molecules that are therapeutically more effective substitutes for available antimalarial drugs against which the malarial parasites have developed resistance. All the five copper complexes of DAP have tetrahedral geometry as revealed by micro-analytical data and spectroscopies. All attempts to grow single crystals of the complexes failed. The metal complexes were more active against gram - positive bacterial and gram-negative bacteria. The complexes were found to be nontoxic as compared to parent drug. The toxicological data supported this finding.

\section{Acknowledgement}

ACT and JAO appreciate the financial support of Science and Technology Education Post Basic Project (Step B) and University of Ilorin, Nigeria

\section{References}

1. Colin D, Therapeutic Drugs, 1, Church Livingstone, 1999, D13 - D18, D111- D113.

2. Ajibola A O, Essential Medicinal Chemistry, $2^{\text {nd }}$ Edn., Shaneson Jersey, 1999, 26.

3. Domarle O, Blampain G, Agnaniet A, Nzadiyabi T, Lebibi J S, Brocard J, S Maciejewski L A, Biot C, Georges A J and Millet P, Antimicrob Agents Chernother., 1998, 42, 540.

4. Tsunali T, Yoshino T, Tanaka T and Watanabe I, Nippon Kagaku Zasshi, 1952, 73, 94.

5. Guangguo I N, Guoping W, Xuchun F and Longguan Z, Molecules, 2003, 8, 287.

6. Garg R K and Sharma L M, J Indian Chem Soc., 1995,72,4231

7. Ogunniran K O, Tella A C, Alensela M and Yakubu M, Afr J Biotech., 2007, 6(10), 1202.

8. Obaleye J A, Caira M R and Tella A C, J Chem Crystallogr., 2007, 37, 707.

9. Obaleye J A, Caira M R and Tella A C, Anal Sci., 2008, 24, 63. 
10. Copper Complexes Recognise DNA Bases, Royal Society of Chemistry, Chemistry World, October, 2005, 10.

11. Collins C H, Microbiological Methods, $3^{\text {rd }}$ Edn., Butterworth's and Co Ltd., 1980, 414.

12. Akanji M A, Olagoke O A and Oloyede O B, Toxicol., 1993, 81, 173.

13. Jeffrey G H, Basset J, Mendham J and Denney R C, Vogel's Textbook of Quantitative Chemical Analysis, $5^{\text {th }}$ Edn., Longman, UK Ltd., 1989, 578.

14. Ferraro J R, Low Frequency Vibration of Inorganic and Coordination Compounds, Plenum Press, New York, 1971, 89.

15. Bult A and Klasen H B, J Pharm Sci., 1978, 67, 284.

16. Passini A, Bersanetti E, Zunino F and Ginuseppina S, Inorg Chim Acta, 1983, 80, 99.

17. Nahamishi K and Solomon P H, Infrared Absorption Spectroscopy, $2^{\text {nd }}$ Edn., Holden day Inc. San Francisco, 1979, 50.

18. Agwara M O, Ndifon P T and Ndikontar M K, Bull Chem Soc Ethiop., 2004, 18, 143.

19. Lever A B, Inorganic Electronic Spectroscopy, Elsevier, Amsterdam, 1984.

20. Roger S M, A Complete Introduction to Modern NMR Spectroscopy, John Wiley \& Sons Inc., 1998, 1.

21. Casanova J, Alzuet G, Ferrer S, Borras J, Garcia-Granda S and Perez-Carreno E, $J$ Inorg Biochem., 1993, 51, 689.

22. Chaudhary A S and Singh R, Bol Soc Chil Quim., 2002, 47, 203.

23. Umezawa H and Hooper I R, Amino glycoside Antibiotics. Springer-Verky, Berlin, Haidelberg, 1982.

24. Malomo S O, Ale O O and Adedoyin A M, Biosci Res Commun., 1993, 5, 53. 


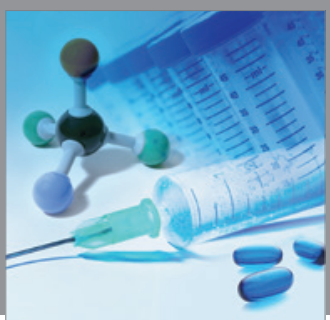

International Journal of

Medicinal Chemistry

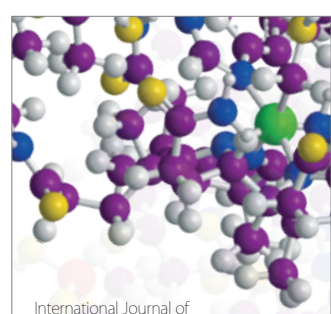

Carbohydrate Chemistry

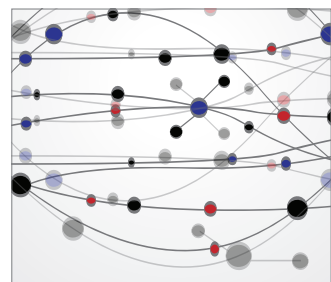

The Scientific World Journal
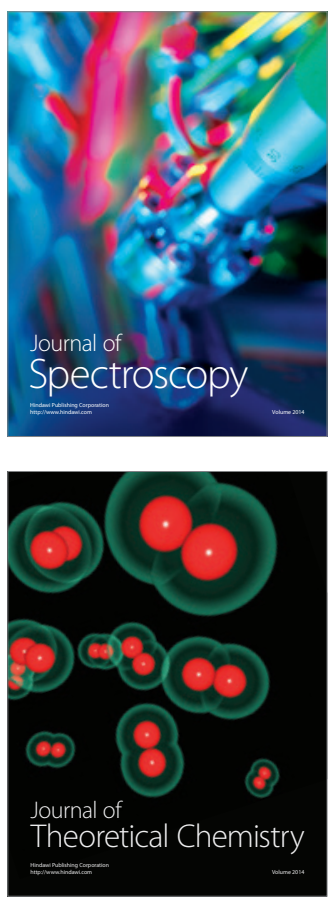
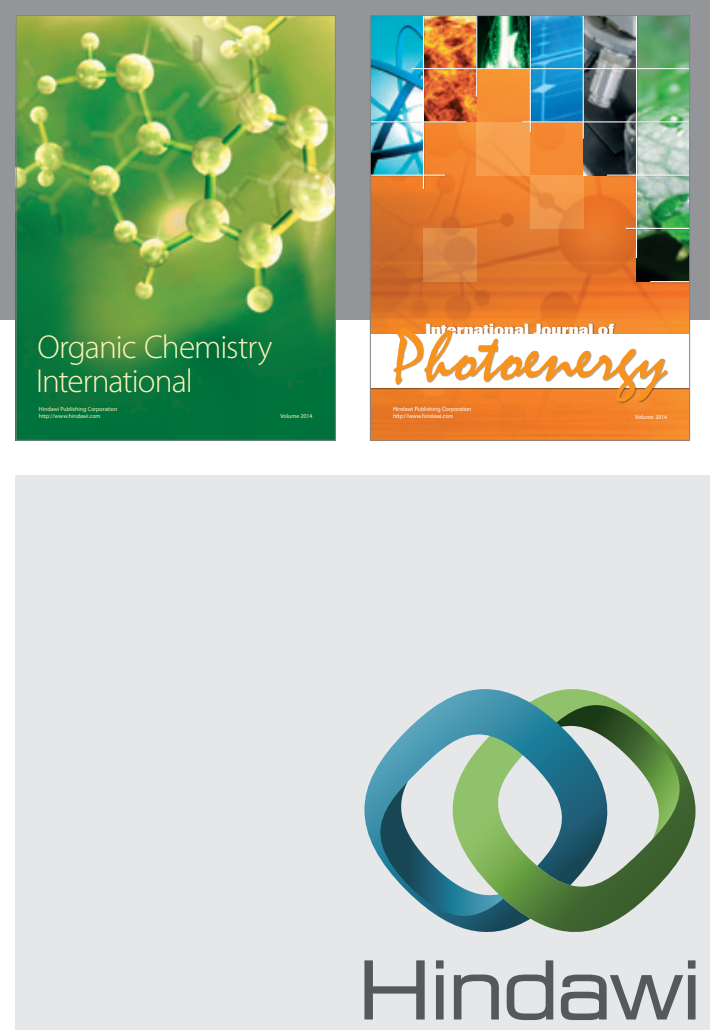

Submit your manuscripts at

http://www.hindawi.com
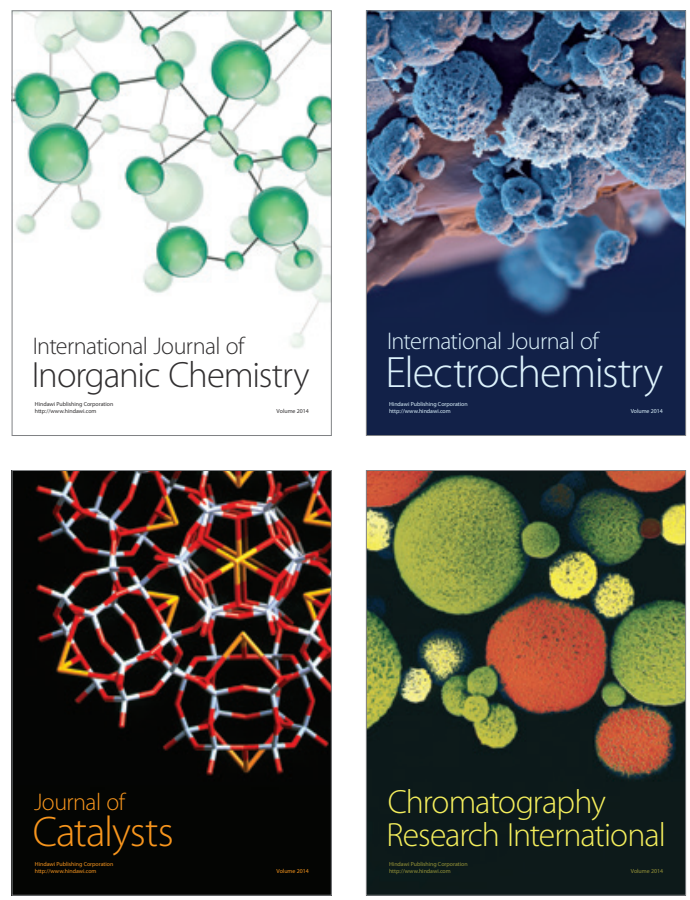
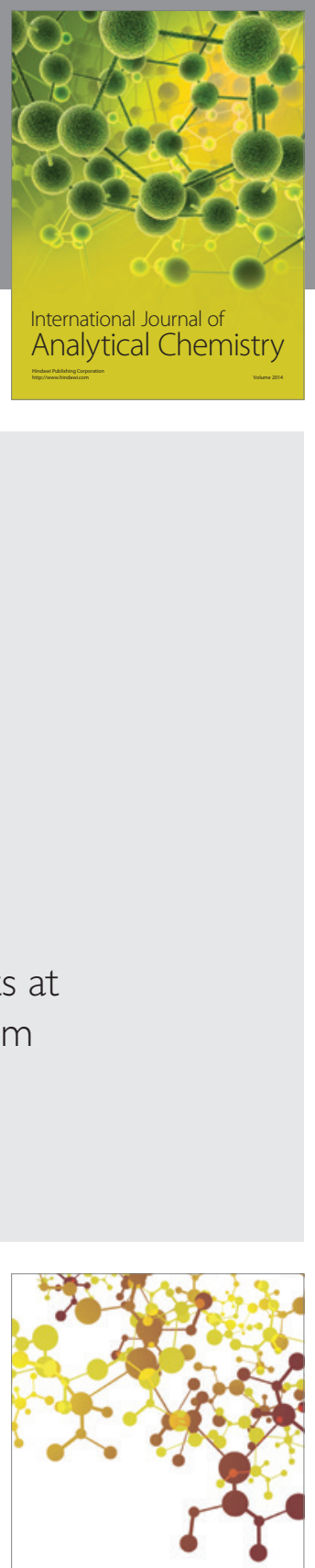

Journal of

Applied Chemistry
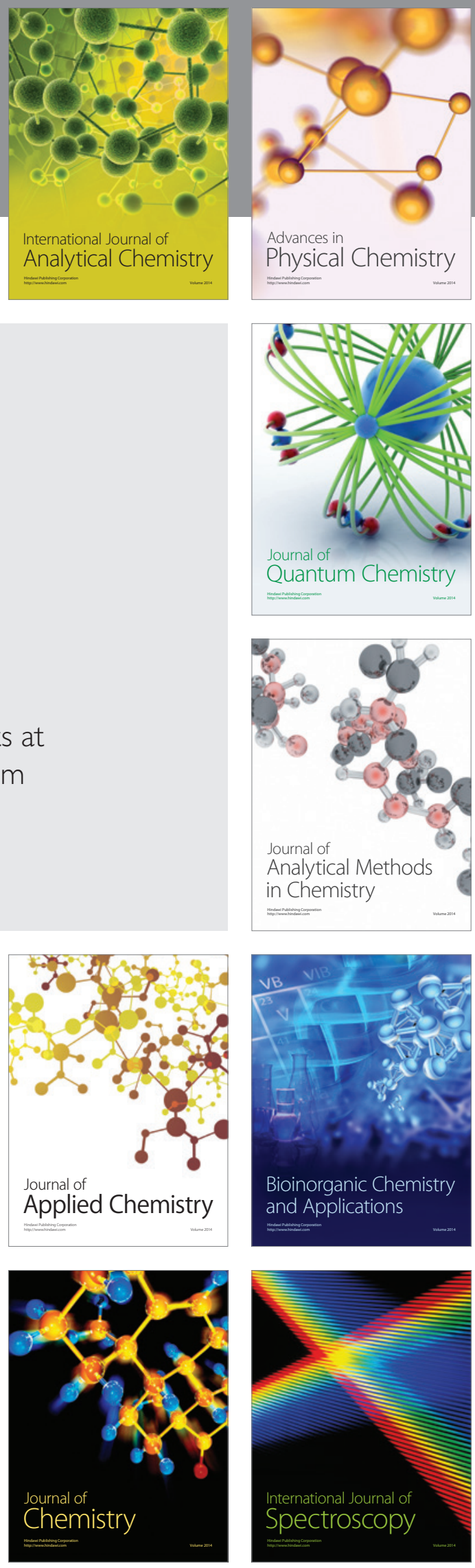